\title{
Meningkatkan Penghasilan Petani Sengon untuk Mendukung Restorasi Kawasan Gambut dengan Model Agroforestri di Desa Gohong, Kabupaten Pulang Pisau
}

\author{
Yeprin Ari Pradana ${ }^{1}$, Yolanda Yussy ${ }^{1}$, Jembar $^{1}$, Adi Jaya ${ }^{1}$, Emmy Uthanya Antang ${ }^{1}$ \\ dan Haris Gunawan ${ }^{2}$ \\ ${ }^{1}$ Fakultas Pertanian, Universitas Palangka Raya \\ ${ }^{2}$ Universitas Riau, Pekanbaru \\ Email : pradanaari11@yahoo.co.id
}

\begin{abstract}
Abstrak
Sejak kebakaran hutan dan lahan gambut Tahun 2015, Pemerintah Republik Indonesia membentuk Badan Restorasi Gambut dengan program utama melakukan restorasi gambut dengan berdasarkan pada Pembasahan kembali (P1), Penanaman pohon (P2) dan Pemberdayaan ekonomi masyarakat (P3) di kawasan lahan gambut. Pada aspek penanaman pohon (P1) akan menjadi menarik minat masyarakat bila dapat dilakukan dengan kombinasi dengan tanaman yang bernilai ekonomi sekaligus juga secara ekologi memungkinkan. Hal ini sejalan dengan perubahan paradigma pengelolaan hutan yang juga sekaligus mensejahterakan masyarakat. Secara umum masyarakat dapat melakukan kegiatan usahatani apabila mereka bisa memperoleh penghasilan yang sifatnya harian (diantaranya berupa tanaman semusim) dan juga jangka panjang berupa tanaman tahunan. Secara ekologis, kombinasi pohon dan tanaman pertanian memungkinkan apabila pada awal pertumbuhannya, tutupan tajuk pohon masih memungkinkan masuknya sinar matahari dan tanaman semusim yang dipilih membutuh naungan dalam jumlah tertentu. Tujuan pengimplementasian agroforestri di daerah ini tidak lepas dari pengelolaan yang lebih mudah dibandingkan dengan bentuk usahatani pertanian umumnya seperti padi sawah atau pertanian monokultur lainnya. Agroforestri juga dinilai dapat memberikan banyak alternatif pendapatan dan produk yang lebih banyak bagi masyarakat di Desa Gohong. Kegiatan kegiatan yang didanai oleh BRG dilakukan pada lahan masyarakat yang memiliki pertanaman dengan pola agroforestri baik tanaman karet, sengon maupun pohon lainnya. Kajian berupa karakterisasi sifat lahan gambut dan aspek biofisik lainnya terkait dengan pertumbuhan tanaman seperti pencahayaan, kelembaban, pertumbuhan tanaman serta pendapatan petani saat ini, selain itu juga dilakukan pengamatan terhadap pola agroforestri yang telah dikembangkan tersebut dan upaya perbaikan yang harus dilakukan.
\end{abstract}

Kata Kunci : restorasi, agroforestri, gambut

\section{Latar Belakang}

Kawasan gambut tropika khususnya di Kalimantan Tengah, banyak mengalami degradasi oleh berbagai sebab diantaranya adalah akibat kebakaran hutan dan lahan rawa gambut. Pemerintah melalui Perpres No.1 Tahun 2016, telah membentuk Badan Restorasi Gambut (BRG) untuk tujuan melakukan konservasi dan restorasi lahan gambut terdegradasi. Secara umum pendekatan terpadu dilakukan untuk konservasi dan restorasi lahan gambut terdegradasi sebagaimana menjadi program BRG yaitu 3P mencakup aspek: P-1 Pembasahan kembali (rewetting), P-2 Penanaman kembali (re-vegetasi), dan P-3 Pemberdayaan ekonomi masyarakat (revitalisasi livelihood). Gambut penting bagi dunia terutama karena simpanan karbon yang besar dan bagi perubahan iklim dunia. Selain itu gambut berperan dalam kehidupan masyarakat setempat. Hampir setiap musim kemarau terjadi kebakaran hutan dan lahan utamanya masih akibat ulah manusia di lingkungan tersebut dan pengelolaan lahan gambut yang kurang bijaksana. Badan Restorasi Gambut yang dibentuk Pemerintah memiliki tugas melakukan restorasi gambut melalui pendekatan 3P (Pembasahan, Penanaman kembali dan Pemberdayaan ekonomi) dan sejak 2017 telah banyak melakukan kegiatan restorasi. Restorasi yang berhasil pada dasarnya bukan hanya memperhatikan aspek ekologi semata tetapi juga kesejahteraan masyarakat sekitarnya yang berkepentingan dengan lahan gambut.

Di Desa Gohong Kecamatan Kahayan Hilir Kabupaten Pulang Pisau telah 
dilaksanakan program dari BRG terkait dengan program P1 pembasahan (rewetting), terutama pembangunan sekat kanal dan sumur bor, namun belum banyak program yang berkaitan dengan penanaman kembali (revegetasi) dan pemberdayaan ekonomi masyarakat. Salah satu kegiatan yang dapat mendukung revegetasi dan pengembangan ekonomi masyarakat adalah dengan mengembangkan agroforestri. Agroforestri adalah salah satu bentuk kehutanan masyarakat, merupakan pengelolaan lahan optimal untuk mendukung penghidupannya. Agroforestri didefinisikan sebagai kolektif dari sistem dan teknologi penggunaan lahan secara terencana pada satu unit lahan dengan mengkombinasikan tumbuhan berkayu (seperti: pohon, perdu, palem, bambu) dengan tanaman pertanian an/atau ternak dan/atau ikan, yang dilaksanakan dalam waktu yang bersamaan atau bergiliran sehingga terbentuk interaksi ekologis dan ekonomis antar berbagai komponen yang ada (Lundgren dan Raintree, 1982). Masyarakat lokal secara tradisional telah melakukan praktek penanaman berbagai jenis pohon dan dipadukan dengan tanaman semusim pada lahan yang sama. Biasanya dilakukan pada lahan yang telah digunakan lagi untuk berladang, sebelum ditinggalkan ditanami dengan karet, pohon buah-buahan, dan sayuran di sela-selanya, dengan teknologi yang sangat minim. Saat ini minat masyarakat untuk melakukan penanaman pohon khususnya pohon lokal sangat rendah karena nilai ekonominya yang rendah dan hanya memberikan penghasilan melalui penjualan benih saja atau bahkan tidak memberikan hasil, sedangkan pohon karet yang menjadi andalan penghasilan masyarakat tidak lagi menjadi perhatian masyarakat karena harganya yang terus turun.

Tujuan pengimplementasian agroforestri di daerah ini tidak lepas dari pengelolaan yang lebih mudah dibandingkan dengan bentuk usahatani pertanian umumnya seperti padi sawah atau pertanian monokultur lainnya. Agroforestri juga dinilai dapat memberikan banyak alternatif pendapatan dan produk yang lebih banyak bagi masyarakat di Desa Gohong.

Namun sejak larangan membakar masyarakat lahan untuk berusahatani, terutama padi, masyarakat kembali memberikan perhatian kepada tanaman Sengon walaupun hasil yang sebagian masyarakat belum pernah melakukan panen Sengon. Mengingat agroforestri sebagai salah satu model penting untuk mendukung program revegetasi dan pemberdayaan ekonomi masyarakat yang menjadi konsep pengelolaan gambut BRG, maka perlu dilakukan identifikasi dan evaluasi praktek agroforestri yang dilaksanakan oleh masyarakat di Desa Gohong.

Kho (2008) mencatat ada tiga tujuan pengembangan agroforestri. Pertama, untuk meningkatkan produktivitas total yakni meningkatkan output produk persatuan unit dan tenaga kerja. Kedua, meningkatkan stabilitas, yakni mengurangi sensitivitas pada fluktuasi jangka pendek dengan cara menyebarkan resiko ke seluruh jenis penyusun hutan yang beragam. Ketiga, meningkatkan keberlanjutan yakni dengan cara memelihara produktivitas jangka panjang melalui perlindungan sumber daya pokok.

Kayu Sengon memiliki prospek pasar untuk industri kayu vinir, industri kayu pertukangan maupun industri kayu panel dan pulp. Jenis ini sudah dikembangkan cukup lama oleh Perhutani sehingga teknis penanganannya tidak menyulitkan pelaksana di lapangan serta pasarnya sudah tersedia. Dengan daur 6 - 10 tahun pengembangan budidaya tanaman sengon diharapkan mampu memberi kontribusi pendapatan baik bagi Perhutani maupun masyarakat dalam jangka waktu lebih cepat. Adanya pembangunan industry pengolahan kayu Sengon di Kabupaten Pulang Pisau mendorong masyarakat di kabupaten ini untuk menanam sengon dalam jumlah yang cukup banyak. Lahan lahan bervegetasi pohon dikonversi menjadi kawasan budidaya sengon termasuk kawasan lahan gambut. Tampaknya budaya bercocok tanam tanpa pemeliharaan yang merupakan budaya umum masyarakat di 
wilayah ini menyebabkan tingkat keberhasilan budidaya sengon masih rendah.

Agroforestri adalah suatu sistem penggunaan lahan yang bertujuan untuk mempertahankan atau meningkatkan hasil secara produktif, ekonomis dan berkelanjutan dengan menggunakan praktek pengelolaan dan pemanfaatan lahan yang sesuai dengan kondisi ekologi, ekonomi dan budaya setempat pada sebidang lahan yang sama atau dengan kata lain bahwa prinsip agroforestri adalah suatu penggabungan dari pengembangan sistem pertanian dan kehutanan pada satu lahan. Budaya masyarakat Dayak dalam bertani berbeda mulai dari ladang yang berpindahpindah, jenis tanaman yang dibudidayakan antara lain padi ladang, dan menanam tanaman jangka panjang yang tidak perlu perawatan rutin dan dipanen beberapa tahun seperti Karet, Sengon dan Petai. Dalam hal ini peneliti ingin melakukan implementasi Agroforestri dengan menanam tanaman sisipan berupa tanaman sayuran dan buah untuk meningkatkan pendapatan masyarakat dan pemanfaatan lahan seefesien mungkin sehingga mengurangi konversi hutan menjadi lahan pertanian. Agroforestri diharapkan bermanfaat mencegah perluasan tanah terdegradasi, melestarikan sumberdaya hutan dan meningkatkan mutu pertanian. Selain itu dengan adanya tanaman sela pada pola agroforestri yang membutuhkan perawatan lebih intensif memberikan kesempatan pemeliharaan tanaman sengon.

\section{Tujuan dan Manfaat}

Tujuan kegiatan adalah :

1. Menganalisis prospek agroforestri,

2. Memberikan contoh dan pemahaman baru tentang teknik usaha tani yang dapat menambah pendapatan masyarakat melalui kegiatan budidaya tumpangsari/tanaman sisipan, sengon yang telah ada dengan tanaman semusim/hortikultura.

3. Memberikan pemahaman tentang peluang usaha masyarakat yang dapat dikembangkan melalui kerjasama dengan Pemerintah Kabupaten Pulang Pisau melalui model usahatani yang dihasilkan dari kegiatan ini.

Manfaat kegiatan adalah:

Kegiatan ini memberikan manfaat bagi pemerintah dan pemangku kepentingan lainnya, bagi masyarakat, serta peneliti muda dan Perguruan Tinggi.

Manfaat bagi pemerintah dan pemangku kepentingan adalah:

- Mendukung pelaksanaan restorasi kawasan lahan gambut yang telah dilakukan di kawasan ini yang telah membangun sekat kanal yang merupakan bagian dari program BRG tahun sebelumnya.

- Sebagai bahan informasi tentang prospek agroforestri yang dapat dikembangkan oleh masyarakat di Desa Gohong

Manfaat bagi masyarakat adalah:

1. Sebagai pengetahuan tentang prospek pelaksanaan agroforestri yang dapat dilaksanakan masyarakat.

2. Sebagai informasi bagi masyarakat dalam upaya pengembangan model usahatani tumpangsari pohon dengan tanaman hortikultura.

Manfaat bagi Peneliti Muda dan Perguruan Tinggi adalah:

1. Meningkatkan pengetahuan dan kreativitas peneliti muda dalam melihat alternatif pemanfaatan sumberdaya alam.

2. Meningkatkan hubungan antara Kampus Universitas Palangka Raya (termasuk didalamnya dengan alumni dan mahasiswa) dengan masyarakat dan pemangku kepentingan lainnya.

\section{Metoda Pelaksanaan}

\section{a. Lokasi Kegiatan}

Kegiatan ini dilaksanakan di Desa Gohong, Kecamatan Kahayan Hilir Kabupaten Pulang Pisau, yang merupakan salah satu lokasi yang telah ditetapkan dalam Panduan PMRGT 2019.

\section{b. Desain Kegiatan}


Kegiatan ini merupakan action research atau kaji tindak terhadap pelaksanaan agroforestri di Desa Gohong. Bagian dari kegiatan kaji tindak adalah survei yang dilaksanakan terhadap masyarakat dan pasar di Desa Gohong, serta pembuatan demplot berupa penanaman jenis tanaman hortikultura di kawasan yang sudah ditanamai sengon.

\section{c. Implementasi Kegiatan}

Tujuan utama dari kegiatan ini adalah untuk mengidentifikasi prospek sistem agroforestri dan potensinya dalam meningkatkan pendapatan petani serta hubungannya dengan restorasi gambut tropika di Desa Gohong, oleh karena itu metode yang digunakan dalam kegiatan ini adalah campuran antara metode kualitatif dan metode kuantitatif.

Responden sebagai sumber informan utama dalam kegiatan ini adalah masyarakat yang mengembangkan tanaman kayu atau tanaman tahunan pada lahan usahanya. Data yang dikumpulkan meliputi data primer dan data sekunder. Data primer merupakan informasi yang didapat langsung dari responden di lapangan, sedangkan data sekunder merupakan telaah pustaka dan dokumen yang didapatkan dari berbagai sumber.

Data primer meliputi:

1. Harga pasaran tanaman hortikultura untuk agroforestri

2. Jumlah petani yang menanam tanaman tahunan (berpotensi sebagai pelaku agroforestri)

Data dikumpulkan dengan cara:

1. Wawancara dengan responden dengan menggunakan kuesioner terstruktur

2. Pengamatan langsung di lapangan.

Analisis data kualitatif dilakukan dengan deskriptif eksplanatory, untuk menjelaskan prospek agroforestri yang dapat dilaksanakan oleh masyarakat Desa Gohong.
Untuk menjawab tujuan kedua dan ketiga dari kegiatan ini dilakukan demplot pelaksanaan usahatani

\section{Hasil Capaian Kegiatan}

\section{a. Pelaksanaan Agroforestri di Desa Gohong}

Berdasarkan hasil survei di Desa Gohong didapat informasi bahwa belum ada masyarakat yang melaksanakan agroforestri sesuai konsep dan pengertian yang sesungguhnya yang merupakan kombinasi antara pohon dan tanaman pertanian, baik kombinasi tanaman sayuran, peternakan, perikanan dan buah-buahan dan hanya menanam tanaman pohon. Dalam konteks budaya tanaman di Kalimantan Tengah pada umumnya, msyarakat membuka hutan dengan menggunakan teknik bakar lahan lalu melakukan budidaya tanaman padi. Setelah lahan tidak lagi produktif, lahan budidaya padi tersebut dikonversi menjadi kebun karet dan buah-buahan. Pada beberapa petani dijumpai kombinasi antara pohon dan tanaman pertanian seperti nanas, pisang, kopi dan lain-lain dalam jumlah yang tidak begitu besar. Pilihan tanaman pertanian didasarkan pada jenis yang tidak membutuhkan perawatan yang intensif. Untuk kebutuhan harian, pasokan sayur-mayur di Desa Gohong berasal dari desa lainnya. Jenis Tanaman pohon yang ditanami oleh masyarakat Gohong adalah Sengon dan Karet.

\section{b. Demplot}

Implementasi agroforestri yang dilakukan dengan membuatkan demplot menggunakan tanaman sisipan berupa kangkung, cabai rawit dan bawang daun di antara pohon sengon, demplot di buat dengan ukuran $1 \times 20$ $\mathrm{m}$ sebanyak 12 bedeng dengan ketinggian bedeng $30 \mathrm{~cm}$, dalam pengolahan lahan masih mengunakan cara manual dengan cangkul, pemberian kapur dolomit untuk menaikan $\mathrm{pH}$ tanah, dan pemberian pupuk kandang untuk menambah kesuburan serta pemberian pupuk organik dan anorganik.

Pemilihan jenis tanaman sela untuk sayuran berupa kangkung, cabai rawit dan 
bawang daun didasarkan pada : 1) nilai ekonomis dan permintaan pasar yang cukup baik dan 2) pemeliharaan tanaman yang cukup dikuasai oleh masyarakat serta tidak membutuhkan waktu yang lama, kecuali tanaman caai rawit serta 3) umur panen tanaman yang relatif pendek yaitu antara 11,5 bulan (kecuali tanaman cabai).
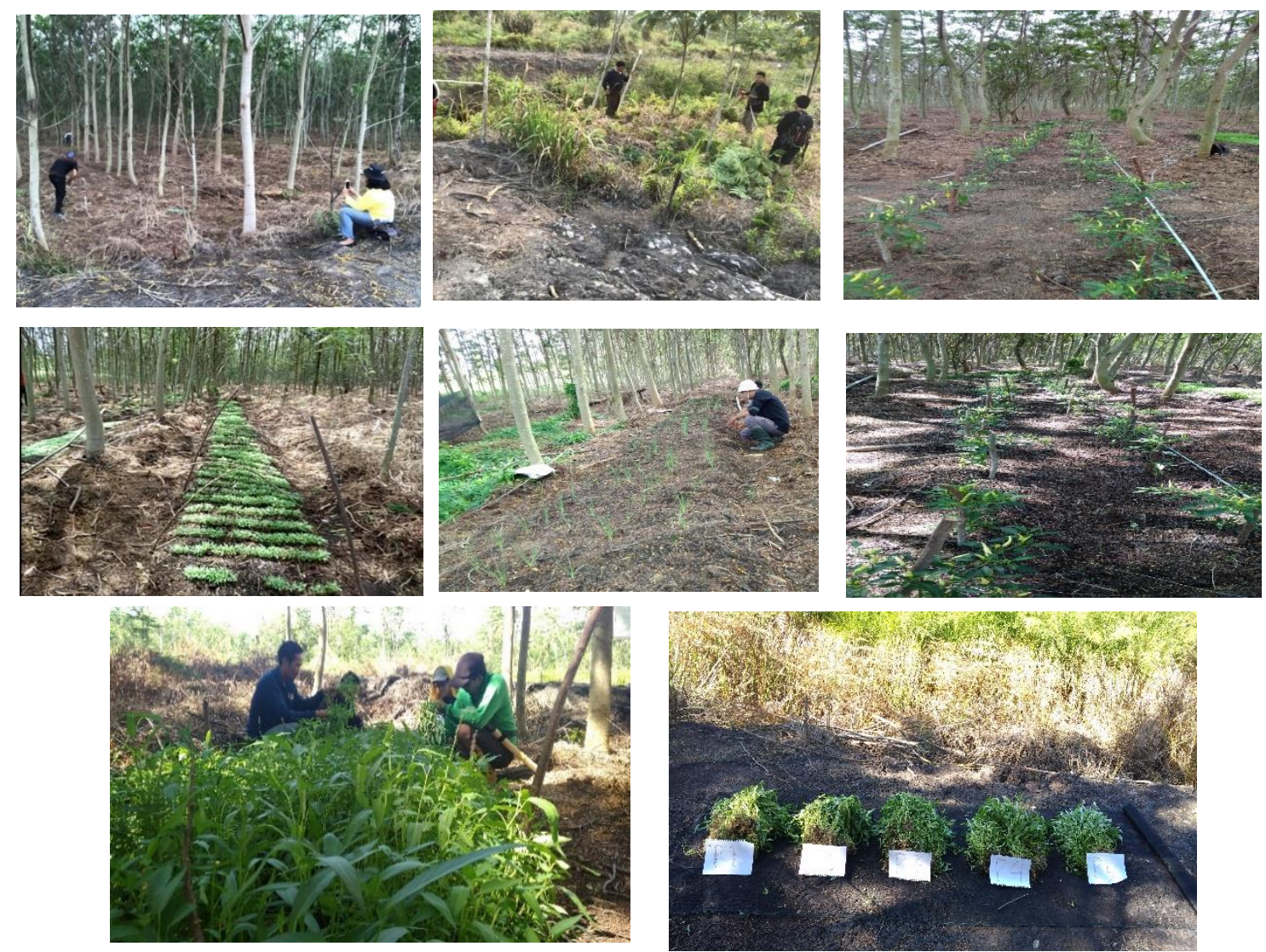

Gambar 1. Rangkaian kegiatan agroforestri mulai persiapan hingga panen

Demplot yang dibuat untuk contoh dari implementasi agroforestri, selama kegiatan dari semua komoditi yang ditanam memiliki daya tumbuh yang baik, namun sampai kegiatan berakhir hanya kangkung yang dapat dipanen sedangkan tanaman yang lain belum cukup umurnya untuk dipanen. Kegiatan ini juga dilakukan diantara umur sengon yang berbeda dari yang besar dengan kondisi setengah tertutup dan sengon kecil yang terbuka dari penyinaran matahari, dari implementasi agroforestri ini diharapkan selain mampu meningkatkan ekonomi masyarakat, masyarakat juga memiliki rasa tanggung jawab menjaga lahan di sekitarnya. Jika masyarakat memiliki asset berupa tanaman maka masyarakat akan berusaha mencegah terjadinya kebakaran, Bertani intensif akan meningkatkan cepat tanggap masyarakat terhadap kebakaran, saat terjadi kebakaran sehingga tidak menjadi luas, atau bahkan berupaya untuk mencegah terjadinya kebakaran dengan melakukan pembersihan lahan secara baik menjelang musim kemarau.

Pilihan budidaya pada kondisi tanaman sengon yang besar, didasarkan pada keinginan untuk mengkaji pertumbuhan dan produksi sayuran sebagai tanaman sela dengan kondisi naungan yang cukup besar sehingga cahaya matahari yang dibutuhkan oleh tanaman pertanian untuk pertumbuhan dan produksinya serta kondisi perakaran tanaman sengon yang diperkirakan sudah cukup banyak, yang dapat menimbulkan persaingan hara Antara pohon dan tanaman sayuran. Hasil kegiatan menunjukkan prospek yang baik bagi budidaya tanaman sayuran disela pohon yang cukup besar. 
Dengan kondisi seperti ini maka apabila ditanam pada sela pohon dengan umur tanaman yang lebih rendah, maka pertumbuhan dan produksi bisa menjadi lebih baik, atau minimal sama dengan pada tanaman sengon yang besar. Terlebih apabila tanaman sengon baru dibudidayakan hamper sama maknanya dengan tanaman sayur yang ditanam secara monokultur.

\section{c. Pembuatan kompos}

Kompos merupakan pupuk organik yang berbahan dasar dari sisa sisa dedauan ataupun tumbuh-tumbuhan. Dalam kegiatan di Desa Gohong ini bahan utama kompos yang digunakan adalah dedaunan kering dari tumbuhan kayu sengon yang akan mengurangi bahan yang flammable (mudah terbakar) guna mengurangi kemungkinan kebakaran pada saat musim kemarau tiba di daerah gambut tropika Desa Gohong.

Berikut beberapa langkah "Demo" pembuatan pembuatan pupuk organik secara sederhana yang dilakukan oleh peneliti muda restorasi gambut tropika di Desa Gohong, yaitu:

1. Mengumpulkan serta menyiapkan bahan utama pupuk kompos yaitu dedaunan kering dari pohon sengon yang ada di perkebunan rakyat.
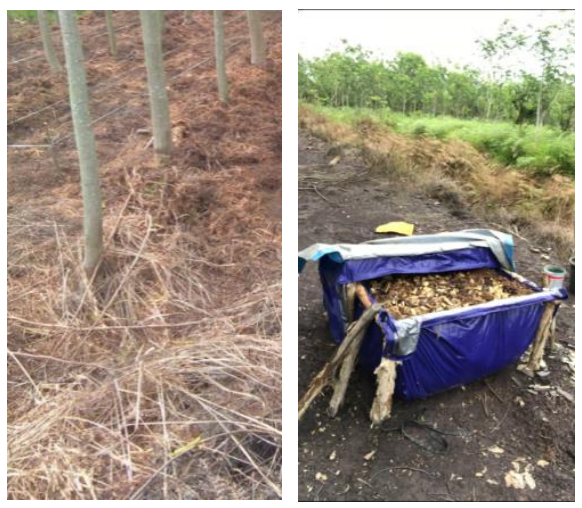

Dari pembuatan kompos ini untuk menunjang dalam budidaya Tanaman Sayuran Sebagai pupuk organik untuk meningkatkan kesuburan tanah dan mampu mengurangi penggunaan pupuk kimia, pembuatan kompos ini menggunakan bahan dari dedaunan sengon sehingga lebih ekonomis, penggunaan dedaunan sengon yang sudah kering berjatuhan bertujuan
2. Menyiapkan wadah berbahan terpal dan kayu serta wadah dilengkapi dengan penutup yang juga berbahan terpal supaya pupuk yang dibuat tidak akan terkontaminasi. wadah berbentuk persegi yang berukuran $1 \mathrm{mx} 1 \mathrm{~m}$. Lalu, memasukkan bahan utama dedaunan kering sengon dengan ketebalan yang sesuai dengan wadah.

3. Menyiapkan campuran bahan untuk fermentasi kompos yaitu mikroorganisme untuk kompos (EM4), air dari kanal, gula merah. Dicampurkan dengan komposisi $100 \mathrm{ml}$ EM4, $1 \mathrm{~kg}$ gula merah, 10 liter air kanal

4. Menyiram wadah berisi dedaunan kering sengon menggunakan campuran bahan fermentasi kompos dengan gembor berkapasitas 5 liter secara perlahan dan merata.

5. Menutup wadah dengan rapat dan biarkan selama seminggu dan cek berkala dengan penambahan bahan campuran fermentasi apabila dirasa perlu sampai saat kompos siap diaplikasikan untuk tanaman.

Berikut gambar bagan langkah atau step "Demo" pembuatan kompos oleh peneliti muda restorasi gambut dengan memanfaatkan dedaunan kering dari perkebunan rakyat di Desa Gohong:

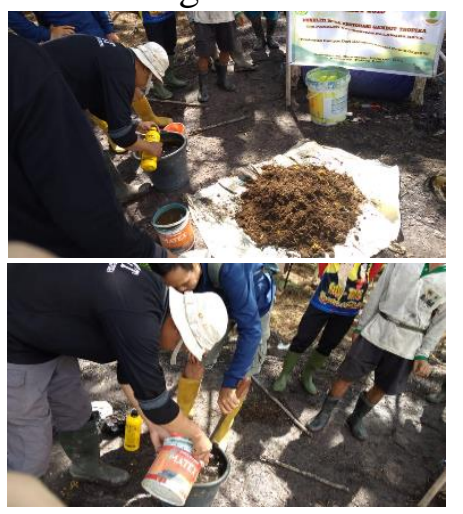

untuk mengurangi pemicu kebakaran saat musim kemarau. Untuk mengurangi pemicu kebakaran dan memanfaatkannya peneliti membuatkan kompos dari dedaunan sengon sebagai pupuk untuk tanaman sisispan.

\section{d. Sekat Kanal}

Air adalah kunci dalam pengelolaan lahan gambut, air dapat memasok kebutuhan 
tanaman yang berpengaruh terhadap dekomposisi (penguraian) dan subsidensi (penurunan permukaan) gambut dan berpengaruh terhadap kondisi bahaya kebakaran. Pada musim kemarau oksidasinya akan berlanjut dan permukaan tanah menjadi makin lama menjadi makin rendah yang menyebab kan kebakaran dilahan gambut. Terkait pencapaian kinerja Untuk mengatur pengelolaan lahan gambut dengan restorasi lahan gambut salah satunya dengan membangun sekat kanal (Canal Blocking). Canal blocking menjadi agenda nasional dalam merestorasi gambut dengan tujuan utamanya mengatasi kebakaran lahan akibat kerusakan ekosistem gambut.
Mencegah kebakaran lahan gambut dengan menjaga lahan gambut tetap basah dianggap merupakan langkah yang lebih efektif.

Tahapan kegiatan yang dilakukan dalam pembuatan sekat kanal adalah: survey untuk pengumpulan informasi yang diperlukan dalam rangka penetapan lokasi, biaya, dan waktu pelaksanaan.

Kanal yang dibuatkan sekat memiliki kedalaman 2 meter dan lebar 4 meter, sekat kanal yang dibuat merupakan tipe 2 (spillway) mengunakan bahan dari kayu galam, papan, terpal dan karung untuk memuat tanah timbunan, sekat kanal dibuat bersama warga Desa Gohong.

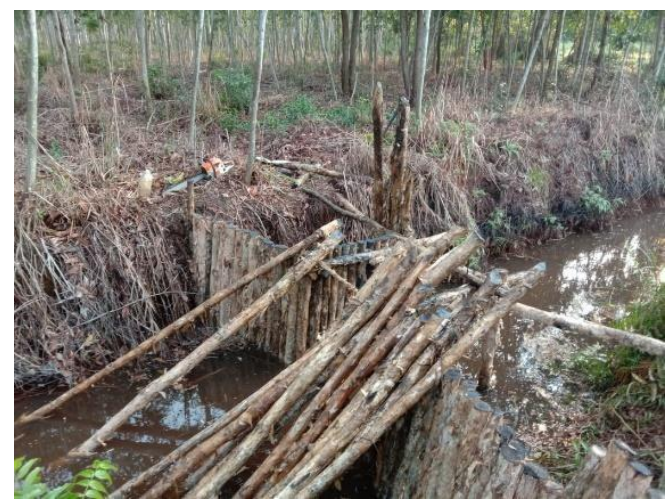

Gambar 2. Proses Pembuatan Sekat Kanal

\section{e. Jembatan ke perkebunan masyarakat (gotong royong)}

Salah satu pendekatan sosial masyarakat Desa gohong adalah menumbuhkan kembali semangat gotong royong dan swadaya masyarakat. Minimnya sarana akses menuju lokasi kegiatan (perkebunan rakyat), masyarakat bersama Peneliti Muda Badan Restorasi Tropika (PMRGT) Universitas Palangka Raya membuatkan jembatan sederhana untuk menunjang ke lokasi kegiatan, Tim Bersama masyarakat membuat jembatan sederhana mengunakan kayu galam dengan ukuran lebar $1 \mathrm{~m}$ dan panjang $6 \mathrm{~m}$.

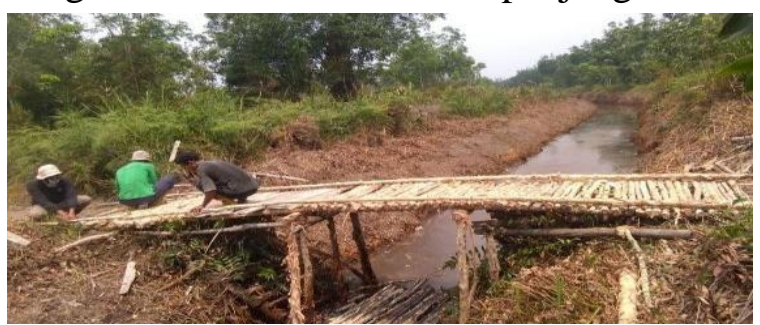

\section{f. Pencapaian Aspek Keberlanjutan (Sosial, Ekonomi, Lingkungan) Prospek Agroforestri}

\section{Keunggulan sistem agroforestri}

Sistem agroforestri menawarkan keunggulan tersendiri dari sistem pesaingnya. Dalam keunggulan tersebut terdapat tujuan untuk meningkatkan kesejahteraan masyarakat, dan sekaligus menciptakan lingkungan yang sehat dalam konteks restorasi gambut tropika. Namun, kenyataan di lapangan menunjukkan bahwa agroforestri mempunyai pesaing dikarenakan mempunyai kesamaan produk (komoditi). Beberapa sistem Sistem agroforestri menawarkan keunggulan tersendiri dari sistem pesaingnya. Dalam keunggulan tersebut terdapat tujuan untuk meningkatkan kesejahteraan masyarakat, dan sekaligus menciptakan lingkungan yang sehat dalam konteks restorasi gambut tropika. 
Namun, kenyataan di lapangan menunjukkan bahwa agroforestri mempunyai pesaing dikarenakan mempunyai kesamaan produk (komoditi). Beberapa sistem pesaing agroforestri yang ada (Gambar 4) antara lain adalah:

- Kehutanan, sebagai penghasil kayu bangunan dan produk non-kayu (Hasil
Hutan Bukan Kayu atau HHBK).

- Hutan Tanaman Industri (HTI) dan Perkebunan sebagai penghasil kayu bangunan dan tanaman keras

- Hortikultura (orchards), sebagai penghasil buah atau rempah

- Pertanian sebagai penghasil tanaman pangan

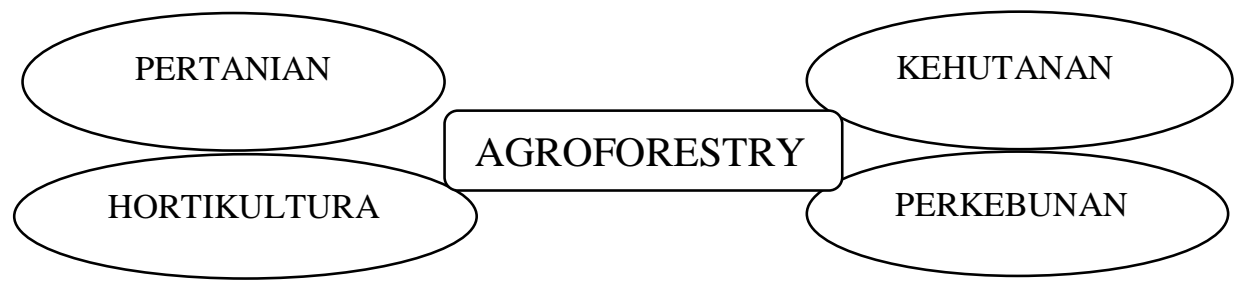

Gambar 3. Skema Sistem Pesaing Agroforestri

Keempat sistem pesaing agroforestri tersebut mempunyai keterbatasan untuk memenuhi tujuan dari paradigma baru pengelolaan kehutanan. Telah banyak kegiatan yang menunjukkan bahwa sistem monokultur mengandung risiko yang cukup besar antara lain serangan hama dan penyakit dalam jumlah besar. Tidak jarang petani mengalami gagal panen, kecuali bila ada usaha pencegahan dan pembasmiannya secara kimia yang dampaknya terhadap lingkungan dan kesehatan sangat merugikan. Selain itu, kelemahan lain dari sistem monokultur, adalah adanya risiko fluktuasi harga pasar.

Berikut beberapa faktor yang mempengaruhi peluang pengimplementasian agroforestri di Desa Gohong, yaitu:

- Mulai adanya kesadaran masyarakat dalam bertani hortikultura dan mengubah pola tanam serta mindset penduduk lokal dimana menanam setelah pengolahan lahan awal akan ditinggalkan tanpa adanya perawatan intensif.

- Besarnya luasan lahan gambut yang dapat memiliki nilai investasi dan berkaitan erat dengan restorasi gambut, dimana kesadaran masyarakat yang mulai meningkat akan bahayanya kebakaran hutan. Dan dengan adanya nilai investasi di lahan mereka maka kesadaran masyarakat akan lebih dirangsang akan perlindungan terhadap api di masing-masing lahannya.
- Adanya perubahan paradigma baru tentang pengelolaan hutan yang lebih mempertimbangkan pengelolaan sumber daya alam (natural resources management) dan usaha meningkatkan kesejahteraan masyarakat yang hidup di sekitar hutan dapat memberikan peluang besar untuk pengembangan agroforestri.

- Meningkatnya kesadaran tentang pengetahuan lokal petani, membuka kesempatan yang luas untuk mempelajari praktek agroforestri yang telah banyak berkembang.

- Kepedulian global pada usaha pengurangan konsentrasi $\mathrm{CO} 2$ di atmosfer dengan jalan meningkatkan cadangan karbon (carbon-stock), mengurangi emisi gas rumah kaca, dan mempertahankan keanekaragaman hayati, telah membuka kesempatan untuk memanfaatkan cadangan karbon dalam agroforestri yang lebih besar dibandingkan dengan pertanian intensif.

- Kepedulian global terhadap kelestarian alam, dengan memberikan penghargaan terhadap produk yang dihasilkan dari pertanian 'hijau' (termasuk agroforestri) semakin meningkat. 
Sistem agroforestri memiliki beberapa keunggulan, yaitu dari segi ekologi/ lingkungan, ekonomi, sosialbudaya dan politik (Darusman, 2002 dalam Hairiah $d k k, 2003)$, dimana:

\section{Keunggulan Ekologi/Lingkungan}

Keunggulan agroforestri dalam ekologi/lingkungan adalah multi-jenis yang artinya memiliki keanekaragaman hayati yang lebih banyak dan ekosistem yang lebih baik daripada monokultur. Di Desa Gohong sendiri dikarenakan sering terjadinya kebakaran hutan maka banyak rantai ekosistem yang terganggu dan dengan adanya agroforestri kebakaran hutan akan lebih ditanggulangi dan kemungkinan tanaman terserang hama lebih minim dibandingkan dengan monokultur.

\section{Keunggulan Ekonomi}

Tanaman yang ditanam lebih beragam, yang biasanya dipilih jenis-jenis tanaman yang mempunyai nilai komersial dengan potensi pasar yang besar. Keragaman atau diversifikasi jenis hasil ini akan meningkatkan ketahanan terhadap fluktuasi harga dan jumlah permintaan pasar. Dengan diperolehnya jenis hasil yang beragam dan berkesinambungan ini akan menjamin pendapatan petani lebih merata sepanjang tahun. Kebutuhan investasi yang relatif rendah, atau mungkin dapat dilakukan secara bertahap. Di Desa Gohong sendiri tidak ada petani penyuplai kebutuhan sayur maka dari itu masyarakat biasanya membeli sayuran dengan penjual keliling dari Desa Mentaren dan membeli sayuran biasanya pada saat diselenggarakannya pasar (hari rabu dan sabtu). Dengan adanya agroforestri diharapkan Desa Gohong akan memebuhi kebutuhan sayurannya sendiri dan dapat menyumbang kontribusi untuk perekonomian individu maupun daerah.

\section{Keunggulan Sosial-Budaya}

Keunggulan sosial-budaya merupakan keunggulan agroforestri yang berhubungan dengan kesesuaian adopsi yang tinggi dengan kondisi pengetahuan, ketrampilan dan sikap budaya masyarakat petani. Dalam pengimplementasiannya agroforestri dinilai memiliki kebutuhan input, proses pengelolaan sampai jenis hasil agroforestri umumnya sudah sangat dikenal oleh masyarakat didampingi dengan pemahaman agroforestri adalah teknologi yang fleksibel dan dapat dilaksanakan mulai dari sangat intensif untuk masyarakat yang sudah maju, sampai kurang intensif untuk masyarakat yang masih tradisional dan subsisten. Serta agroforestri menganut filosofi budidaya yang efisien, yakni memperoleh hasil yang relatif besar dengan biaya atau pengorbanan yang relatif kecil.

\section{Keunggulan Politik}

Keunggulan politik dalam pengimplementasian atau adopsi agroforestri bagi kepentingan masyarakat secara luas dan politis adalah dengan adanya nilai dari lahan masyarakat ada nilai investasi dari tanaman agroforestri tidak hanya lahan kosong) masyarakat akan direspon dengan tanggung jawab atas kepemilikan lahan dan menjaga sumber daya yang memberi manfaat nyata kepada mereka. Agroforestri dapat dan sangat cocok dilakukan oleh masyarakat luas, adanya pemerataan kesempatan usaha, serta menciptakan struktur supply yang lebih kompetitif. Agroforestri dapat pula meredakan ketegangan atau konflik politik, yang selama ini terus memanas akibat ketimpangan peran antar golongan dan ketidakadilan ekonomi serta kebakaran lahan gambut yang rentan dijadikan isu politik.

\section{g. Prospek pemasaran tanaman hortikultura yang dapat dijadikan tanaman sisipan di Desa Gohong}

Peluang pemasaran di Desa Gohong mengingat desa ini bukan merupakan sentra produksi sayuran dan menerima supply sayuran dari Desa Mentaren dan dari daerah lain sangatlah baik dan menguntungkan dikarenakan 
diperlukannya tanaman hortikultura atau sayuran untuk meningkatkan taraf kesehatan dan kesejahteraan (ekonomi) masyarakat. Maka pemasaran sayuran masih sangat minim dan hanya memiliki 2 saluran pemasaran (perantara). Berikut merupakan saluran pemasaran yang terjadi di Desa Gohong:

\section{Saluran I (saluran 1 tingkat)}

Saluran pemasaran I adalah saluran pemasaran memiliki 1 (satu) perantara dari produsen ke konsumen yaitu perantara yang memasarkan sayuran dengan menggunakan kendaraan keliling (pedagang pengecer) Desa Gohong dari Desa Mentaren 1.

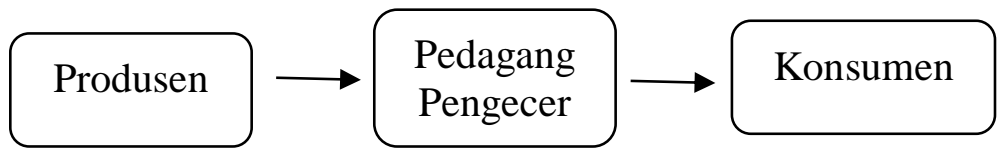

Gambar 4 Saluran Pemasaran I

Saluran II (saluran dua tingkat)

Saluran pemasaran II adalah saluran pemasaran 2 (dua) tingkat yaitu memiliki dua

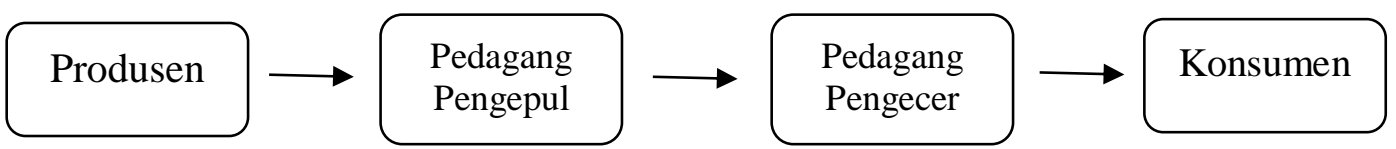

Gambar 5 Saluran Pemasaran II

Tabel 1. Harga Rata-Rata Pemasaran Sayuran Hortikultura yang Berpotensi sebagai Tanaman Sisipan Tahun 2019 di Desa Gohong, Kabupaten Pulang Pisau, Kalimantan Tengah Tahun 2019

\begin{tabular}{|c|l|l|l|c|}
\hline No & \multicolumn{1}{|c|}{ Nama Bahan Produk } & \multicolumn{1}{|c|}{ Satuan } & \multicolumn{1}{|c|}{$\begin{array}{c}\text { Harga } \\
(\mathrm{Rp})\end{array}$} & Tanggal \\
\hline 1. & Kangkung & 1 ikat & 3.000 & 28 Desember 2019 \\
\hline 2. & Bawang Daun & 1 ikat & 2.000 & 28 Desember 2019 \\
\hline 3. & Bayam Cabut & 1 ikat & 2.000 & 28 Desember 2019 \\
\hline 4. & Lombok (Cabe) & 1 genggam & 2.000 & 28 Desember 2019 \\
\hline
\end{tabular}

Sumber : Data Primer, 2019

Berikut perhitungan keuntungan dari program demplot yang sudah dilakukan para peneliti: Dalam 1 bedengan dengan ukuran 1 x20 meter hasil panen kangkung mencapai berat $34,8 \mathrm{Kg}$ atau 1.020 ikat, jika mengikuti harga jual dari petani ke pengepul Rp.1.500/ikat maka hasil yang di dapat dari 1 bedengan adalah Rp. $1.500 \times 1.020$ ikat $=$ Rp. 1.530.000.

Dari hasil analisis usaha tani petani memiliki keutungan awal sebesar Rp. 314.000 untuk tanaman kangkung dengan luasan bedengan 1x20 m, dengan umur tanaman 20 hari. Jika tanaman kangkung ditanam setiap minggu pada bedengan yang berbeda akan dihasilkan tambahan pendapatan sebesar Rp. 314.000. Dan jika tenaga kerja yang digunakan adalah tenaga kerja dalam keluarga, maka rumah tangga tidak perlu mengeluarkan biaya untuk tenaga kerja yang artinya ada penambahan pendapatan sebesar Rp. 650.000.

Jika implementasi Agroforestri tanaman sisipan kangkung dengan luasan 1 ha dengan ukuran bedengan 1x20 meter maka terdapat 500 bedengan, jika dalam 1 bedengan didapat berat $34,8 \mathrm{~kg}$ maka dalam $34,8 \mathrm{~kg}$ x $500=$ 17,25 ton/Ha atau 510.000 ikat, jika mengikuti harga jual dari petani ke pengepul Rp. 1.500/ikat maka hasil yang di dapat dari 500 bedengan adalah Rp. 1.500 x 510,000 ikat maka hasil yang didapat dalam 1 ha adalah Rp. 765.000.000. 
Tabel 2. Analisis Usaha Tani tanaman sisipan kangkung

\begin{tabular}{|c|c|c|c|c|}
\hline \begin{tabular}{|r|} 
Uraian \\
\end{tabular} & Volume & Satuan & Harga & Jumlah \\
\hline \multicolumn{5}{|l|}{ A. Biaya Tetap } \\
\hline 1. Sewa lahan & $20 \mathrm{~m}^{2}$ & & & Rp. 100.000 \\
\hline Total & & & & Rp. 100.000 \\
\hline \multicolumn{5}{|l|}{ B. Biaya Variabel } \\
\hline 1. Alat & & & & \\
\hline a. Cangkul & 1 & Buah & Rp. 90.000 & Rp. 90.000 \\
\hline b. $\quad$ Sprayer & 1 & Buah & Rp. 45.000 & Rp. 45.000 \\
\hline c. Gembor & 1 & Buah & Rp. 55.000 & Rp. 55.000 \\
\hline 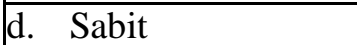 & 1 & Buah & Rp. 40.000 & Rp. 40.000 \\
\hline 2. Bahan & & & & \\
\hline a. $\quad$ Benih & 1 & & Rp. 35.000 & Rp. 35.000 \\
\hline b. $\quad$ Pupuk Kandang & 20 & $\mathrm{Kg}$ & Rp. 35.000 & Rp. 35.000 \\
\hline Urea & 1 & $\mathrm{Kg}$ & Rp. 9.000 & Rp. 9.000 \\
\hline Cair Organik & & & Rp. 100.000 & Rp. 100.000 \\
\hline Kapur Dolomit & 10 & $\mathrm{Kg}$ & Rp. 30.000 & Rp. 30.000 \\
\hline Total & & & & Rp. 439.000 \\
\hline 3. $\quad$ Tenaga Kerja & & & & \\
\hline a. $\quad$ Pengolahan Tanah & 2 & $(1 \mathrm{HOK})$ & Rp. 50.000 & Rp. 100.000 \\
\hline b. Penanaman & 1 & $(1 \mathrm{HOK})$ & Rp. 50.000 & Rp. 50.000 \\
\hline c. Pemupukan & 1 & $(1 \mathrm{HOK})$ & Rp. 100.000 & Rp. 100.000 \\
\hline d. Pemeliharaan & 1 & $(1 \mathrm{HOK})$ & Rp. 300.000 & Rp. 300.000 \\
\hline e. Panen & 2 & $(1 \mathrm{HOK})$ & Rp. 100.000 & Rp. 100.000 \\
\hline Total & & & & Rp. 650.000 \\
\hline Total Biaya Produksi & & & & Rp. 1.189.000 \\
\hline Hasil & 1.020 & Ikat & Rp. 1.500 & Rp. 1.530.000 \\
\hline Keuntungan & & & & Rp. 341.000 \\
\hline
\end{tabular}

Perhitungan yang terdapat pada Tabel 2 menggunakan asumsi perhitungan alat yang digunakan hanya pada 1 bedeng tetapi hasil yang didapatkan dapat pula diterapkan pada asumsi apabila lahan memiliki luasan $1 \mathrm{Ha} /$ 500 bedeng, maka dari perhitungan hasil total penjualan yaitu Rp. 1.530 .000 - total biaya peralatan yaitu Rp. 230.000 x 500 bedeng = Rp.650.000.000. Maka penerimaan bersih yang didapat dari $1 \mathrm{Ha}$ Lahan/500 bedeng adalah Rp.650.000.000.

\section{h. Potensi dan kendala pengembangan agroforestri}

Dalam pengimplementasian dan pengembangan agroforestri tentunya ada beberapa hal yang akan menjadi kendala dalam penerapannya apabila tidak diperhatikan secara mendalam dan detail, halhal tersebut antara lain: Jaminan penguasaan lahan, tenaga kerja dan ketrampilan, dan informasi harga pasar komoditas.

Potensi pengembangan agroforestri adalah kebutuhan tenaga kerja yang rendah akan menarik masyarakat untuk mempraktekkan agroforestri, pengetahuan dan keterampilan yang terus berkembang ditingkat masyarakat, masyarakat dengan mudah memperoleh bibit pohon berkualitas baik, serta masyarakat akan memperoleh masukan lainnya, misalnya bimbingan dan penyuluhan, informasi harga pasar, dukungan kebijakan dan sebagainya. Sebagai keluaran yang diharapkan dari Agroforestri adalah untuk meningkatkan kesejahteraan masyarakat di Desa Gohong, juga ditujukan untuk pelestarian lingkungan dan restorasi kawasan gambut tropika, sehingga kualitas hidup masyarakat dapat meningkat pula. 


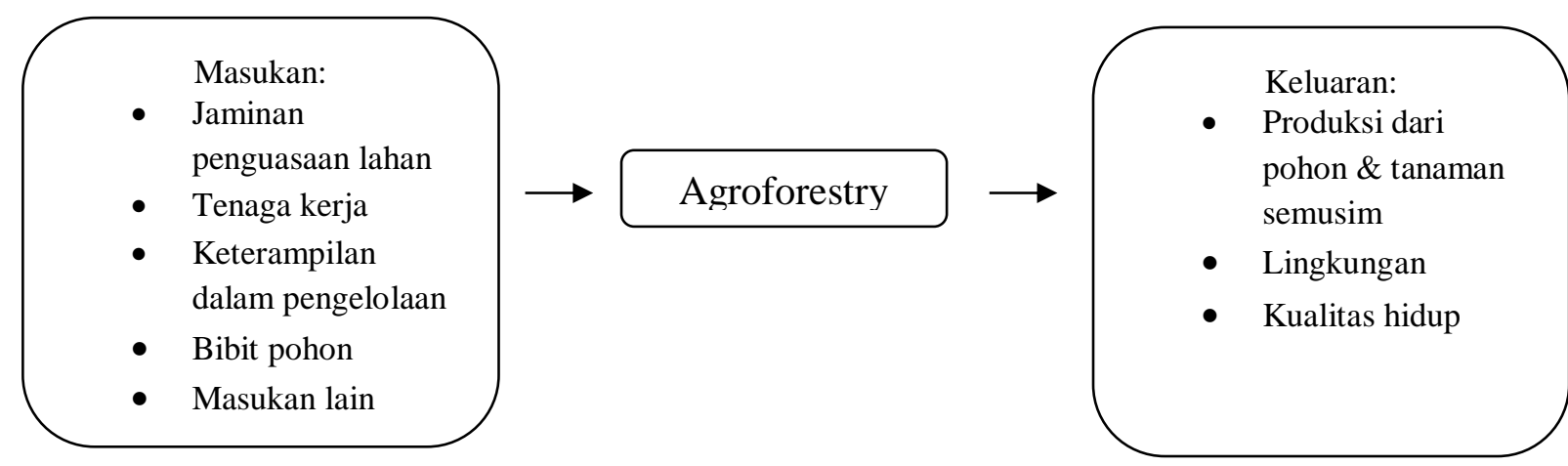

Gambar 6. Hubungan skematis antara masukan dan keluaran dalam pengembangan agroforestri

\section{i. Pendekatan \\ dalam pengembangan} agroforestri

\section{Pendekatan Komoditas dan Pengolahan Lahan}

Pendekatan komoditas merupakan pendekatan terhadap berbagai tanaman yang berpotensi untuk menjadi tanaman sisipan seperti tanaman kangkung, lombok, bawang daun, nenas, dan lain sebagainya. Selain itu, hal yang harus diperhatikan adalah pohon yang menjadi tanaman kayu, ciri dan sifat pohon yang akan menjadi tumpang sari (agroforestri). Informasi dari hasil kegiatan bahwa di Desa Gohong kurang adanya minat dalam menanam pohon dikarenakan sulitnya pemasaran hasil panen dan harga yang tidak menentu dan cenderung rendah dari biaya perawatan. Akses untuk mendapatkan bahan tanaman yang berkualitas tinggi masih merupakan faktor pembatas utama bagi petani. Akses pasar serta harga hasil pohon yang berasal dari agroforestri sangat tergantung dari aturan perusahaan maupun kelembagaan yang mudah sekali berubah. Produsen skala kecil kurang mengetahui informasi tentang aturan jual-beli yang terkait dengan konsumen dan kualitas yang diinginkan.

Berdasarkan pada programa BRG yaitu P1 (pembasahan kembali) dan P2 (penanaman kembali) besar kaitannya dengan pengolahan lahan gambut, dimana pengolahan lahan gambut berlandaskan pada penyediaan lahan untuk proses penanaman kembali. Mengingat dalam penanaman dan pengolahan lahannya untuk tanaman budidaya berbeda dari tanah mineral, tanah gambut memerlukan beberapa perlakuan tambahan seperti pengapuran, pemberian pupuk dengan dosis 1:2 yang diberikan pada tanah mineral. Di Desa Gohong sendiri $\mathrm{pH}$ tanahnya 4,39 dan $\mathrm{pH}$ air nya adalah 2,75 dan tergolong asam. Maka dari itu perlu diterapkannya perlakuan khusus dibandingkan tanah mineral biasa.

\section{Pendekatan Masyarakat dan Pemerintah}

Pendekatan masyarakat erat kaitannya dengan pengimplementasian dan adopsi dalam pencapaian agroforestri. Berikut beberapa faktor-faktor yang mempengaruhi petani atau masyarakat dalam mengambil keputusan untuk mengadopsi, menolak, mengadaptasi atau mengembangkan sistem agroforestri, yaitu :

a. Faktor pengetahuan lokal petani yang mencakup pengetahuan formal maupun informal, kapasitas petani dalam mengadopsi teknologi, ketrampilan yang dimiliki, dan nilai/manfaat dari agroforestri yang ditawarkan.

b. Faktor sosial, meliputi jaminan penguasaan lahan, intensif atas fungsi pelayanan lingkungan, dan dukungan kelembagaan lokal.

c. Faktor pasar terutama berhubungan dengan input, produk, tenaga kerja dan ketersediaan kredit.

d. Pengembangan dan penyuluhan yang dapat membantu petani dalam memahami, menguji, dan menerapkan sistem agroforestri. 
Berikut Gambar mengenai Interaksi Petani Dengan Faktor Luar Lainnya:

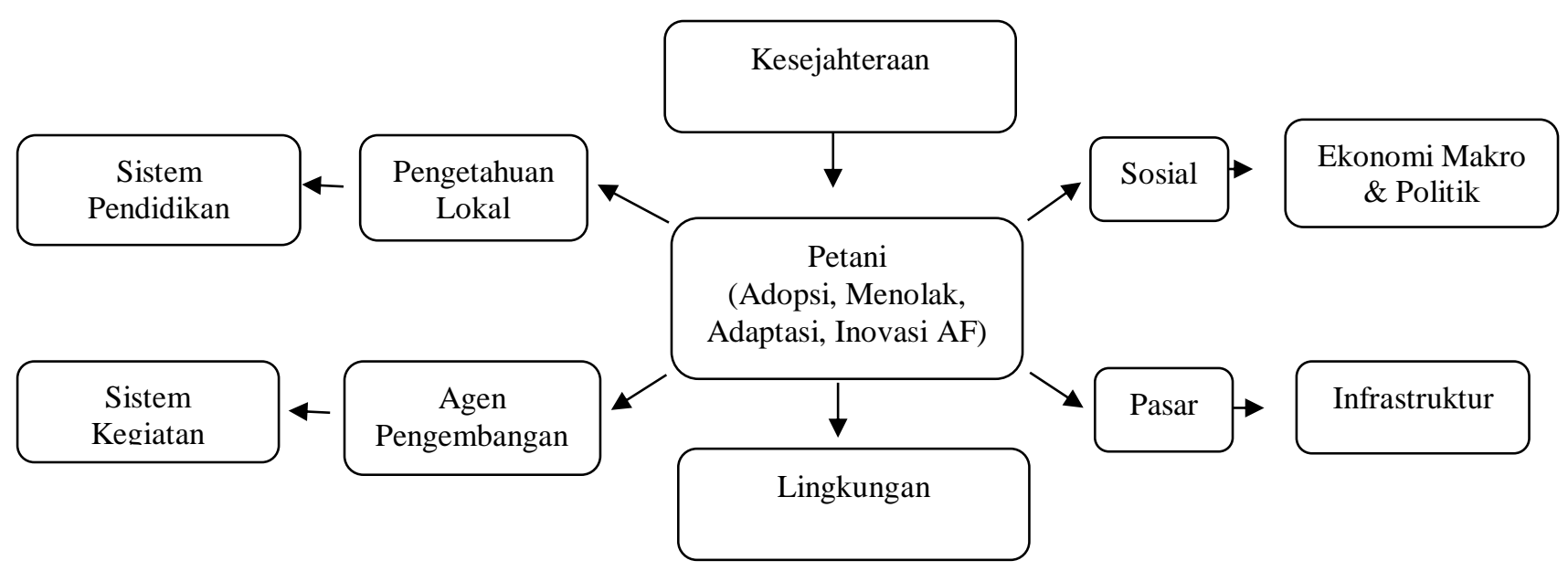

Gambar 7. Interaksi Petani Dengan Faktor Luar Lainnya

Peran pemerintah sangat diperlukan dalam pengimplementasian agroforestri dimana menurut hasil survei kepada beberapa masyarakat keluhan yang disampaikan berupa kurang diangkatnya suatu komoditas dan produk sentra dari suatu daerah misalnya saja di Desa Gohong yang merupakan sentra pengrajin rotan masih belum penyedia bahan baku setengah jadi dan masih belum ada jalur pemasaran ke luar negeri yang besar mengingat mulai berminatnya masyarakat internasional dengan kerajinan rotan yang ramah lingkungan daripada produk plastik dan sintetis serta kurangnya pengangkatan harga komoditas seperti karet dan sengon yang mengurangi minat masyarakat dalam berbisnis. Tetapi dalam beberapa sisi pemerintah banyak membantu misalkan saja programa BRG sendiri merupakan bantuan pemerintah dan bergerak sangat aktif dalam peningkatan taraf hidup dan infrastruktur di Desa Gohong.

\section{j. Tantangan, Masalah dan Pembelajaran}

Implementasi Model Agroforestri menjadi suatu tantangan bagi peneliti PMRGT untuk membuka wawasan masyarakat memberikan pemahaman agrofoterstry dan pemanfaatan lahan semaksimal mungkin, serta bercocok tanam di lahan yang belum pernah digunakan untuk bercocok tanam sayuran menjadikan sebuah tantangan..
Masalah yang dihadapi mulai dari akses jalan menuju lokasi kegiatan, cuaca yang kurang mendukung mulai memasuki musim penghujan sehingga menghambat kinerja di lapangan, kurangnya pemahaman masyarakat tentang agroforestri yang selama ini dipahami masyarakat gohong berbeda.

Tim PMRGT melakukan implementasi dengan ujicoba membuatkan demplot di antara pohon sengon barulah masyarakat memahami agroforestri dan minat untuk mencoba budidaya tanaman sayuran di sela-sela tanaman sengon dan Tim PMRGT UPR juga memberikan contoh cara membuat kompos, pembuatan kompos dari dedaunan kering juga membantu mengurangi resiko penyebaran api saat kebakaran dan memanfaatkan kompos sebagai pupuk tambahan untuk tanaman sehingga kedepannya petani bisa membuat pupuk sendiri.

\section{Kesimpulan dan Saran}

\section{Kesimpulan}

Dari hasil kegiatan ini dapat disimpulkan :

1. Prospek untuk pengembangan agroforestri di Desa Gohong sangat bagus hal ini dapat dilihat dari hasil ujicoba yang dilakukan dengan pembuatan mini demplot, dan pasar yang bagus sehingga masyarakat Desa Gohong bisa memenuhi kebutuhan akan 
sayur-mayur bahkan bias dijual di desaDarusman. 2002. dalam Hairiah K, Utami S.R, lainnya.

Verbist B, Noordwijk M.V, Sardjono M.A.

2. Hasil yang telah dilakukan peneliti menunjukan adanya keuntungan dari budidaya sayuran di antara pohon sengon sehingga diyakini mampu menambah pendapatan masyarakat dari penerapan agroforestri.

3. Adanya peran pemerintah dalam hal dukungan baik alat maupun bahan untuk mengembangkan model usaha tani dengan cara agroforestri.

\section{Saran}

1. Dari hasil kegiatan ini disarankan masyarakat yang berminat untuk menerapkan agroforestri agar bisa mengembangkan model usaha tani agroforestri dengan lahan yang lebih luas dan mencoba komoditi yang berbeda.

2. Pembuatan kompos sangat potensial dikembangkan karena limbah daun sengon kering berlimpah, dan diperlukan alat pencacah agar proses pembuatan kompos lebih cepat.

3. Perlu dukungan stimulan bagi masyarakat untuk mulai mengembangkan usahatani tumpangsari tanaman sayur/hortikultura dengan pohon, sehingga pelaksanaan agroforestri dapat dikembangkan di desa Gohong.

4. Diperlukan fasilitasi dari pemerintah daerah dalam menunjang pengembangan pelaksanaan agroforestri.

\section{Ucapan Terima Kasih}

Ucapan terima kasih kepada Badan Restorasi Gambut yang telah mendanai kegiatan ini melalui kegiatan Peneliti Muda Restorasi Gambut Tropika.

\section{Daftar Pustaka}

Cutler, D., M. Elchinger, G. Hill, J. Katz, dan J. Barnett 2014. Community Agroforestri in Mamuju: A Green Prosperity Model Project. National Renewable Energy Laboratory. Denver.

2003 . Prospek Kegiatan Dan Pengembangan Agroforestri Di Indonesia. Universitas Brawijaya. World Agroforestri Center (ICRAF).

Haggar, J., R. Munguia, M. Barrios, A. Ponce. E. de M. F. Virginio, M. Bolan, S. Romero, M. Merlo, G. Soto, P. Moraga, and C. Staver. 2011. Coffee agroecosystem performance under full sun, shade, conventional and organic management regimes in Central America, Agroforest Syst 82 : 285-301.

Kholifah, Ulfa Nur., Christine Wulandari., Trio Santoso dan Hari Kaskoyo. 2017. Kontribusi Agroforestri terhadap Pendapatan Petani Di Kelurahan Sumber Agung Kecamatan Kemiling Kota Bandar Lampung. Jurnal Sylva Lestari Vo. 5 No.3 (39-47).

Khususiyah, Noviana. dan Suyanto. 2015. Kontribusi Agroforestri dalam Meningkatkan Pendapatan dan Pemerataan Pendapatan Masyarakat Pengelola Hutan Kemasyarakatan di Sesaot Lombok. Prosiding Seminar Nasional Agroforestri 2015: Inovasi Agroforestri Mendukung Kemandirian Bangsa. Balai Kegiatan dan Pengembangan Teknologi Agroforestri. Bandung.

Kho Ramun M. 2008. Approaches to treeenvirontment-crop interactions. Batish Daizy R, Ravinderr KK, Shibu J dan Harminder PS (ed). Ecological Basis of Agroforestri. CRS Press.

Lundgren BO and JB Raintree. 1982. Sustained Agroforestri. In Nestel B (Ed.). 1982.

Agricultural Research for Development. Potentials and Challenges in Asia.

ISNAR, The Hague, The Netherlands. 3749.

Lundgren BO and JB Raintree. 1982. Sustained Agroforestri. In Nestel B (Ed.). 1982. Agricultural Research for 
Development. Potentials and Challenges in Asia. ISNAR, The Hague, The Netherlands. 37-49.

Namwata, Baltazar M.L., Zacharia S. Masanyiwa, dan Omari B.Miziral. 2012. Productivity of The Agroforestri System and Its Contribution to Household Income Among Farmer in Lushoto District, Tanzania. International Journal of Physical and Social Sciences, Volume 2 , Issue 7.

Raintree, J.B.;Young, A.1983. Guidelines for agroforestri diagnosis and design. Nairobi, ICRAF.

Prasmatiwi, F.E., Irham, A. Suryantini, dan Jamhari. 2010. Analisis keberlanjutan usahatani kopi di kawasan hutan Kabupaten Lampung Barat dengan pendekatan nilai ekonomi lingkungan. Pelita Perkebunan 26(1) : 57-69.

Peraturan Desa Gohong Nomor : 02 Tahun 2016 Tentang Rencana Pembangunan Jangka Panjang menengah Desa (RPJM Desa) Tahun 2006 - 2011. Profil Desa. Pemerintah Desa Gohong, Kecamatan
Kahayan Hilir, Kabupaten Pulang Pisau, Provinsi Kalimantan Tengah.

Sri Suharti. 2011. Kajian Pengembangan Komoditi AUK untuk peningkatan pendapatan masyarakat sekitar hutan. Seminar Nasional Reformasi Pertanian Terintegrasi Menuju Kedaulatan Pangan

Tata, Hesti L., Elok Mulyoutami., Endri Martini. 2013. Analisis Kelayakan Finansial Beberapa Pola Agroforestri di Daerah Tapanuli, Sumatera Utara. Prosiding Seminar Nasional Agroforestri.

Taugourdeau, S., G. le Maire, J. Avelino, J.R. Jones, L.G. Ramirez, M.J. Quesada, F. Charbonnier, F. Gómez-Delgado, J.M. Harmand, B. Rapidel, P. Vaast, and O.Roupsard. 2014. Leaf area index as an indicator of ecosystem services and management practices: An application for coffee agroforestri. Agriculture, Ecosystems and Environment 192:19-37.

Zega, S.B., Agus Purwoko., Tri martial. Analisis Pengelolaan Agroforestri dan Kontribusinya terhadap Perekonomian Masyarakat.

file:///C:/Users/User/Downloads/4537-11437-1PB\%20(3).pdf

\section{Lampiran Dokumentasi}

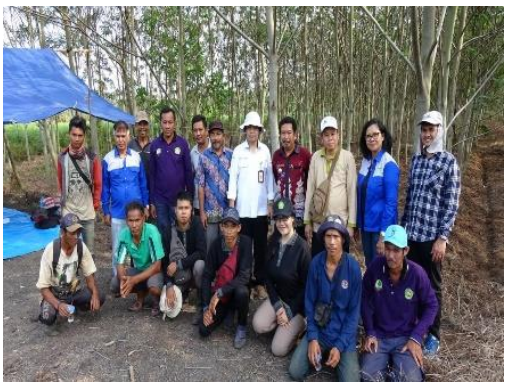

Kunjungan Deputi IV

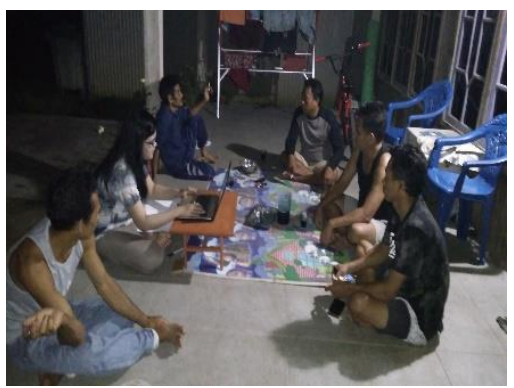

Berdiskusi dengan petani

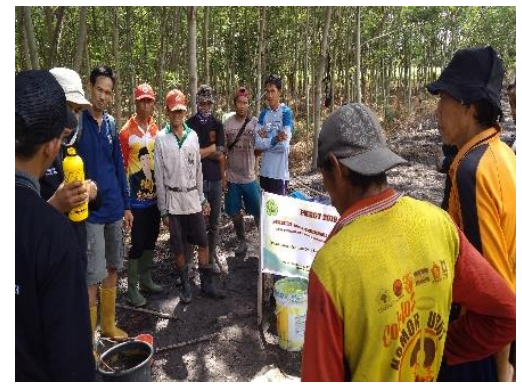

Berdiskusi dengan petani

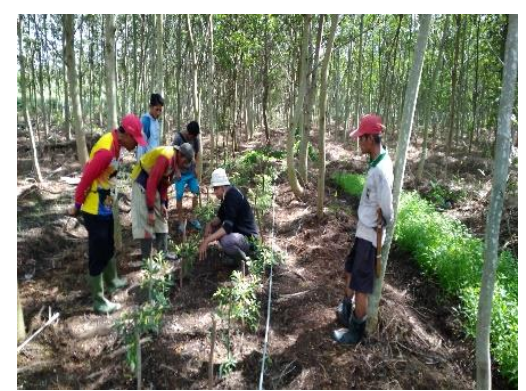

Foto bersama petani

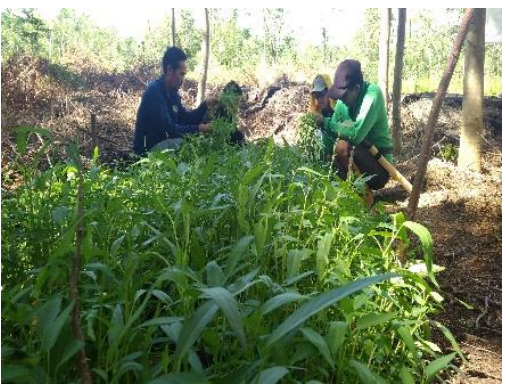

Panen Sayuran Kangkung

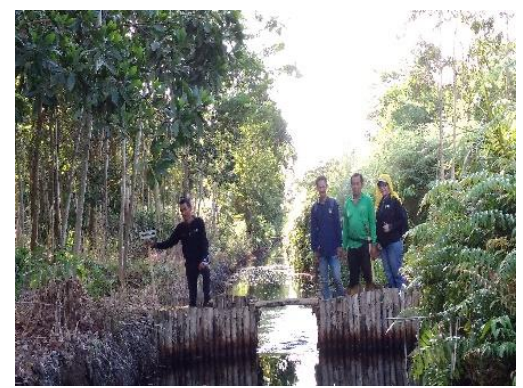

Foto Sekat Kanal 